\title{
Współczesna architektura wieżowców w stolicy Kataru - Dausze
}

\author{
Jerzy Szołomicki ${ }^{1}$, Hanna Golasz-Szołomicka ${ }^{2}$ \\ ${ }^{1}$ Zakład Fizyki Budowli i Komputerowych Metod Projektowania, Wydziat Budownictwa Ladowego \\ iWodnego, PolitechnikaWrocławska,e-mail: jerzy.szolomicki@pwr.edu.pl \\ ${ }^{2}$ Katedra Historii Architektury, Sztuki i Techniki, Wydziat Architektury, Politechnika Wrocławska, \\ e-mail: hanna.golasz-szolomicka@pwr.edu.pl
}

Streszczenie: W artykule przedstawiono elementy analizy architektonicznej i konstrukcyjnej wybranych wieżowców ze stolicy Kataru Dohy zlokalizowanych w dzielnicy biznesowej West Bay oraz w kompleksie sportowym Aspire Zone. Analizując architekturę Dohy można stwierdzić, że obecnie jest to bardzo szybko rozwijająca się metropolia, która jest uznawana wraz z Dubajem za najbardziej zaawansowane technologicznie miasto świata w kategorii budynków inteligentnych ${ }^{1}$. Koniunktura budowlana i rozwój konstrukcyjny spowodowały wznoszenie ikonicznych wieżowców, obiektów widowiskowo-sportowych oraz muzeów. W pierwszej części artykułu zwrócono uwagę na to jak w ciągu kilkunastu lat Doha dołączyła do najciekawszych architektonicznie miast świata ze względu na gwałtowny rozwój gospodarczy wynikający ze znalezienia ogromnych złóż ropy naftowej i gazu ziemnego. Punktem zwrotnym była organizacja XV Igrzysk Azjatyckich w 2006 roku. W wyniku sukcesu ekonomicznego tych igrzysk ponad 100 budynków wysokich i wysokościowych było planowanych do budowy w dzielnicy biznesowej West Bay i przyległych dzielnicach. Oczywiście rozwój architektoniczny miasta nie mógłby się odbyć bez uczestnictwa w nim wybitnych zagranicznych architektów takich, jak na przykład Jean Nouvell, Ieoh Pei, czy Arata Isozaki. W drugiej części artykułu omówiono wieżowce w dzielnicy West Bay: Doha Tower, Al Bidda Tower, Tornado Tower oraz znajdującą się w kompleksie sportowym Aspire Tower. Budynki te stanowią obecnie znak rozpoznawczy Kataru na całym świecie.

Słowa kluczowe: Architektura Kataru; budynki wysokościowe; system konstrukcyjny Diagrid.

\section{Wprowadzenie}

W ciągu czterech dekad historii Doha zmieniła swoje oblicze z wioski rybackiej i wioski poławiaczy pereł $\mathrm{w}$ nowoczesną metropolię $\mathrm{z}$ innowacyjną i futurystyczną architekturą. Wcześniej katarska tradycyjna architektura charakteryzowała się niskimi domami z przestronnymi dziedzińcami. W latach 60 -tych zaczęto budować budynki o średniej wysokości. Następnie, wraz ze wzrostem bogactwa wynikającego z eksportu ropy naftowej i gazu ziemnego oraz szeroko pojętego biznesu na początku lat 90-tych wzrosło zainteresowanie budowaniem budynków wysokich, szczególnie w dzielnicy West Bay. ${ }^{2} \mathrm{~W}$ począt-

${ }^{1}$ Ocena ta została wykonana przez amerykańskie organizacje: technologiczną Honeywell i budownictwa zrównoważonego Green Energy.

${ }^{2}$ West Bay - dzielnica biznesowa w Doha zlokalizowana nad zatoką Doha Bay we wschodniej części miasta, obejmująca wiele współczesnych wieżowców. 
kowym stadium rozwój Dohy był wielkim wyzwaniem dla lokalnych i zagranicznych architektów. Starano się zachować arabską tożsamość i dziedzictwo narodowe oraz zrównoważyć je z wymaganiami funkcjonalnymi, klimatycznymi i energooszczędnymi budynków wysokich. Obecnie Katar i kraje Zatoki Perskiej doświadczają narodzin nowej wyróżniającej się i unikalnej arabskiej architektury $[1,2]$. Region West Bay oraz Aspire Zone ${ }^{3}$, w których zbudowano oryginalne budowle jest przykładem eklektycznych stylów architektury. Rozwój w Katarze objawił się również położeniem znacznego nacisku na kulturę, a co się z tym wiąże ustanowieniem w stolicy Kataru Dausze głównego centrum kulturalnego regionu Zatoki Perskiej. Krajowa Rada Sztuki, Kultury i Dziedzictwa Narodowego zaplanowała szeroki program budowy budynków kulturalnych takich, jak muzea i biblioteki. Do wzięcia udziału w tym projekcie zostali zaproszeni światowej sławy architekci i projektanci. Przykładem tego może być Muzeum Sztuki Islamskiej zaprojektowane przez wybitnego amerykańskiego modernistycznego architekta Ieoha Pei’a.

$\mathrm{Na}$ Bliskim Wschodzie wiele miast inwestuje w budowanie wieżowców. Przykładowo należą do nich Dubaj i Abu Zabi w Zjednoczonych Emiratach Arabskich, Kuwejt City w Kuwejcie, Manama w Bahrajnie, Mekka, Dżudda i Rijad w Arabii Saudyjskiej. Wieżowce te, wraz ze wzrostem ich liczby, bardzo szybko zmieniają oblicze tych miast. Nowy trend tworzy architektoniczny paradygmat przesuwając uwagę $\mathrm{w}$ kierunku projektowania zrównoważonego. Wysokie budynki zrównoważone stały się niezwykle ważne w XXI wieku wraz ze wzrostem populacji ludności w obszarach miejskich.

Głównym kryterium doboru prezentowanych wieżowców Dohy była ich oryginalna forma geometryczna oraz innowacyjna konstrukcja typu diagrid. W budynku Doha Tower po raz pierwszy w historii wykonano ten system jako konstrukcję żelbetową. O potwierdzeniu słuszności wyboru prezentowanych budowli świadczą przyznane nagrody dla najbardziej interesujących budowli świata uzyskane zaraz po ich realizacji. Dlatego autorzy opisując współczesną architekturę budynków wysokościowych tego regionu świata uznali je za wzorzec zasługujący na pełne rozpoznanie. Ponadto zgodnie ze współczesnym trendem prezentowane budynki należą do budynków zrównoważonych. Lokalizacja tych wieżowców w paśmie wzdłuż zatoki West Bay oraz ich oryginalna forma i ikoniczny charakter nasuwa skojarzenie z dzielnicą Manhattan w Nowym Jorku. Ponieważ miasto Doha jest obecnie centrum sportu, w artykule nie mogło zabraknąć charakterystyki najwyższego budynku Kataru Aspire Tower. Budynek ten położony jest w kompleksie sportowym Aspire zone, a jego kształt symbolizuje płomień Igrzysk Azjatyckich z 2006 roku. W ostatnich latach odbyły się tutaj Igrzyska Azjatyckie, Igrzyska Arabskie oraz większość zawodów w różnych dyscyplinach sportowych o puchar Azji. W 2022 roku odbędą się w Dausze mistrzostwa świata w piłce nożnej.

Analizując architekturę budynków wysokościowych w Katarze należy stwierdzić, że od 2006 roku nastąpił znaczny zwrot w kierunku architektury regionalnej i ekologicznej, gdzie zauważa się największy wpływ lokalnych kultur. I tak wśród prezentowanych wieżowców można wyróżnić następujące analogie: Tornado Tower oraz Al Bidda Tower swoim kształtem przypominają wirujące tornado na pustyni, które jest bardzo częstym zjawiskiem atmosferycznym w tym kraju, natomiast Doha Tower ma kształt podobny do gołębnika, charakterystycznej budowli dziedzictwa kulturowego w krajach arabskich.

3 Aspire Zone - kompleks sportowy zlokalizowany w południowo-zachodniej części Dohy, wybudowany w pierwszym etapie na Igrzyska Azjatyckie w 2006 roku, a obecnie rozbudowany o stadion piłkarski Khalifa Stadium przygotowany na mistrzostwa świata w 2022 roku. 


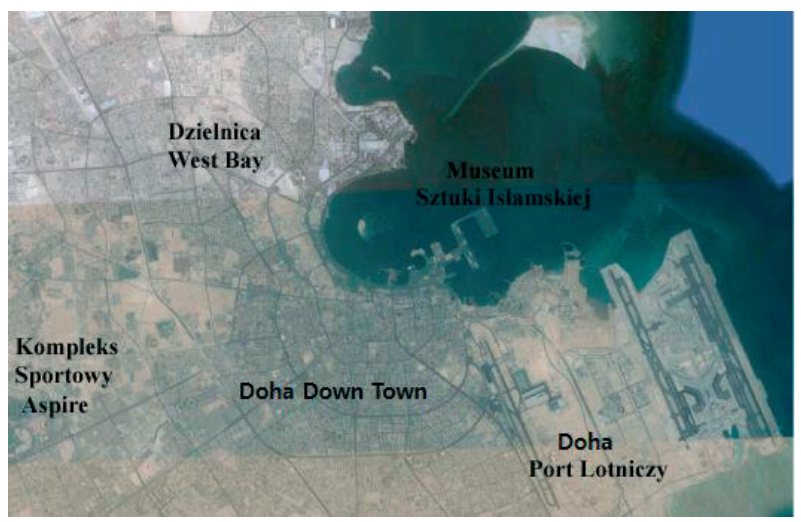

Rys. 1. Lokalizacja dzielnicy West Bay i kompleksu sportowego Aspire na tle planu miasta Doha, opracowanie autorów na podstawie [3]

\section{Historia budowy budynków wysokościowych w Dausze}

Państwa Zatoki Perskiej od kilkunastu lat uczestniczą w wyścigu wybudowania najwyższego budynku świata. Wznoszenie budynków wysokich w Katarze stało się możliwe dzięki wzrostowi bogactwa kraju generowanemu przez ekonomiczny dobrobyt wynikający z eksportu ropy naftowej i gazu ziemnego. Chociaż ropa naftowa była odkryta w 1937 roku przez Petroleum Development Qatar w Dukhan w zachodniej części kraju, jej produkcja rozpoczęła się po II wojnie światowej w czasach katarskiej modernizacji urbanistyki. Pierwszy dochód uzyskany z wydobycia ropy naftowej był głównie zainwestowany w rozwój infrastruktury takiej, jak budowa regionalnych dróg łączących pola naftowe Dukhanu z Dohą i budowę pierwszego portu lotniczego we wschodniej części miasta. Stosownie do ogromnych zasobów ropy naftowej i gazu ziemnego proces dywersyfikacji rozpoczął się później niż w sąsiadujących krajach Zatoki Perskiej. Dodatkowo największe na świecie pole gazowe odkryto w północnej części półwyspu katarskiego na początku lat 70-tych. Jednak produkcja skroplonego, naturalnego gazu rozpoczęła się 20 lat później, w 1991 kiedy ukończono przemysłowe miasto Ras Laffan [4].

Aż do połowy lat 60-tych większość budowli stanowiły pojedyncze tradycyjne budynki, które odpowiadały istniejącym warunkom socjo-kulturalnym. W latach 70-tych Doha uległa transformacji w zmodernizowane miasto. Ważnym elementem tej transformacji było zaprojektowanie głównej drogi Al Corniche ${ }^{4}$. Znaczącym punktem w historii rozwoju Dohy było wyznaczenie w 1974 roku brytyjskiego urbanistę Llewlyna Luisa do zaprojektowania planu urbanistycznego obejmującego centrum Dohy.

Jego projekt opierał się na stworzeniu systemu dróg rozchodzących się koncentrycznie. W oparciu o nowy strefowy plan urbanistyczny zostało utworzone nowe centrum miasta z wielokondygnacyjnymi budynkami mieszkalnymi. Inną równolegle przeprowadzaną inwestycją, zaprojektowaną przez amerykańskiego architekta Williama Perreira, było poszerzenie powierzchni zabudowy poprzez zmianę linii brzegowej zatoki Doha Bay. Zaproponowano na tym terenie w północnym krańcu Al Corniche projekt hotelu Sheraton oraz budowę nowego centrum biznesowego West Bay.

${ }^{4} \mathrm{Al}$ Corniche - główna droga prowadząca wzdłuż wybrzeża zatoki Doha Bay do hotelu Sheraton, który był pierwszym znaczącym budynkiem wybudowanym w dzielnicy West Bay. 
Rozwój i zmiany zwolniły w latach 80 -tych i na początku lat 90-tych z powodu problemów ekonomicznych i politycznych. W tych latach Katar zależał od bogactw naturalnych i warunków ekonomicznych dyktowanych przez kraje Zatoki Perskiej. Pod koniec lat 90-tych Katar zaplanował zrealizowanie różnych projektów inwestycyjnych zarówno w publicznych, jak i prywatnych sektorach. Rezultatem szybkiego procesu budowlanego była organizacja Igrzysk Azjatyckich w 2006 roku. W wyniku sukcesu ekonomicznego w dzielnicy biznesowej West Bay prowadzono prace budowlane na szeroką skalę w 6 strefach (Rys. 2). Proces modernizacji Dohy przybrał kształt taki, jak w Dubaju jako głównego ośrodka inwestycyjnego w Katarze. Na niewielkim obszarze realizowana jest bardzo duża liczba inwestycji budowlanych, do których należą: metro w Dausze, centrum medyczne Sidra, Lusail City, miasto przemysłowe Katar Ras Laffan, Qatar Entertainment City, Projekt Alpha oraz stadiony piłkarskie na mistrzostwa świata w 2022 roku (Doha Port, Al Khor, Khalifa, Al Wakrah, Al Shamal i Umm Slal). W związku z tak dużą skalą inwestycji budowlanych rozbudowa miasta odbywa się również na sztucznie utworzonych wyspach (Prarl, Al Safiya, Palm, Al Aliva).

Obecnie zatoka Doha Bay od północy zamknięta jest hotelem Sheraton natomiast od południa Muzeum Sztuki Islamskiej (zaprojektowane przez amerykańskiego architekta Ieoha Pei’a), które znajduje się również na sztucznie utworzonej wyspie.

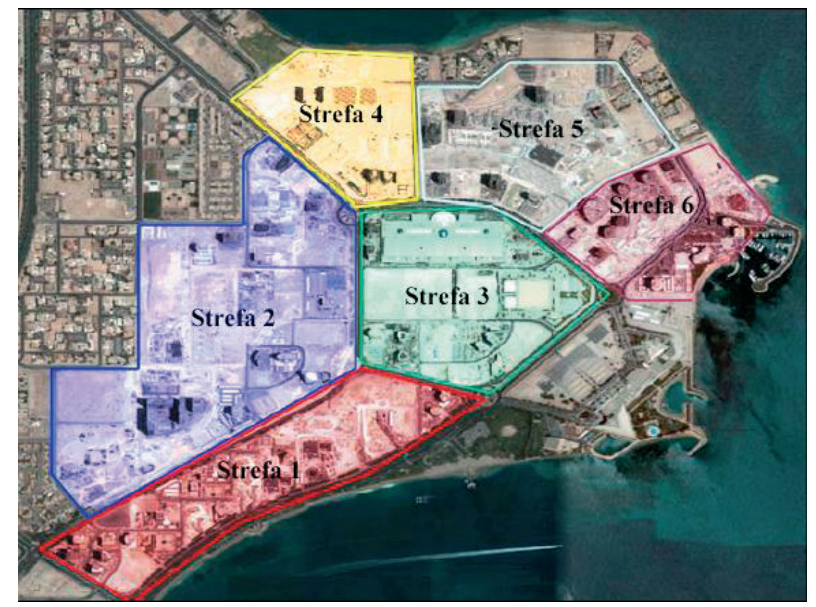

Rys. 2. Podział na strefy budowlane w dzielnicy West Bay, opracowanie autorów na podstawie [3]

\section{Analiza wybranych budynków wysokościowych w Dosze}

Doha jest szybko rozwijającą się metropolią, w której od 2007 roku do dnia dzisiejszego wybudowano 33 budynki powyżej $150 \mathrm{~m}$, co plasuje to miasto na 33 miejscu na świecie przy zdecydowanie najmniejszej zajmowanej powierzchni wśród klasyfikowanych krajów. Współczesne budynki wzniesione wzdłuż drogi Al Corniche tworzą niezwykłą panoramę widoczną z centrum miasta. Wieżowce te mają różną wysokość, która zwiększa się stopniowo począwszy od budynku Qatar Petroleum District, aż do najwyższych wież World Trade Center i Palm Towers i stopniowo zmniejszając swą wysokość aż do zamykającego zatokę najniższego budynku hotelu Sheraton, nawiązując kształtem do fali. 


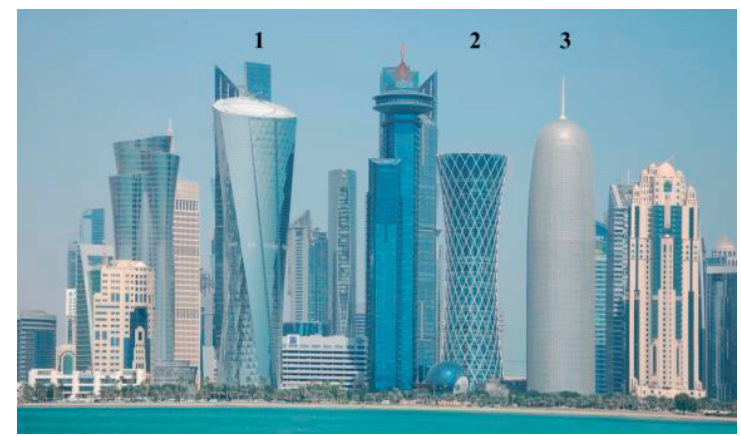

Rys. 3. Panorama wieżowców w dzielnicy West Bay w Dausze: 1 - Al Bidda Tower, 2 - Tornado Tower, 3 - Doha Tower, fot. wykonana przez autorów

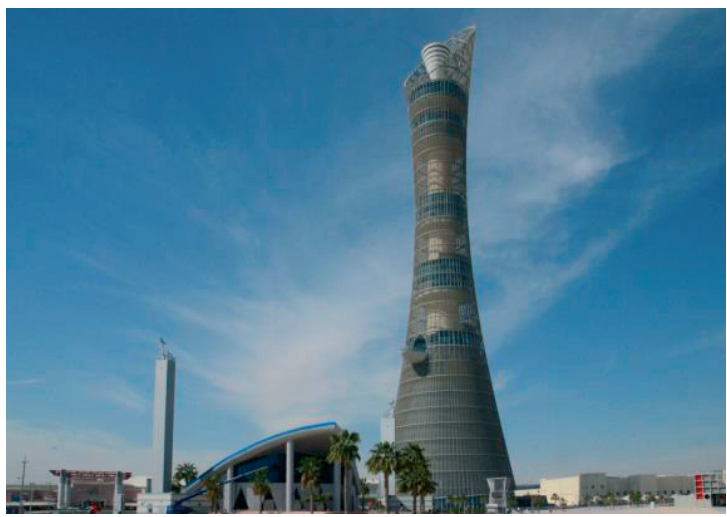

Rys. 4. Aspire Tower w kompleksie sportowym Aspire Zone (2005, projekt Hadi Simaan), fot. wykonana przez autorów

Analizując współczesną architekturę budynków wysokościowych Dohy wzięto pod uwagę dwa urbanistyczne regiony: Al Dafne i Al Waab. W celu przybliżenia charakteru budynków wysokościowych obu regionów szczegółowym analizom poddano trzy wieżowce z regionu Al Dafne: Doha Tower, Al Bidda Tower i Tornado Tower oraz Aspire Tower $\mathrm{z}$ regionu Al Waab w kompleksie sportowym Aspire Zone. Analizom poddano formę geometryczną, konstrukcję oraz system fasadowy budynków.

Al Dafna jest regionem nadmorskim Dohy zlokalizowanym na terenie West Bay. Region ten został utworzony w połowie lat 80-tych stosownie do rozległego projektu urbanistycznego i zaczął rozwijać się bardzo dynamicznie od połowy lat 90-tych w ważne centrum biznesowe. Obecnie dzielnica West Bay jest preferowaną lokalizacją dla wielu prężnie rozwijających się biur, rządowych ministerstw, licznych międzynarodowych spółek naftowych i gazowych oraz rezydencji.

Pierwszą ważną budowlą tego regionu był hotel Sheraton, którego piramidalna bryła była przez wiele lat architektoniczną ikoną symbolizującą miasto (Rys. 5). Podczas procesu modernizacji Dohy, przyjęto nowe normy budowlane ${ }^{5}$ dla projektowania budowli wysokościowych [5].

\footnotetext{
${ }^{5}$ Normy budowlane dla budynków wysokich w Katarze określają, że wysokość budynków powinna być
} w zakresie 15-56 pięter, a otoczenie wokół nich powinno być wolne od zabudowy w promieniu $6 \mathrm{~m}$. 


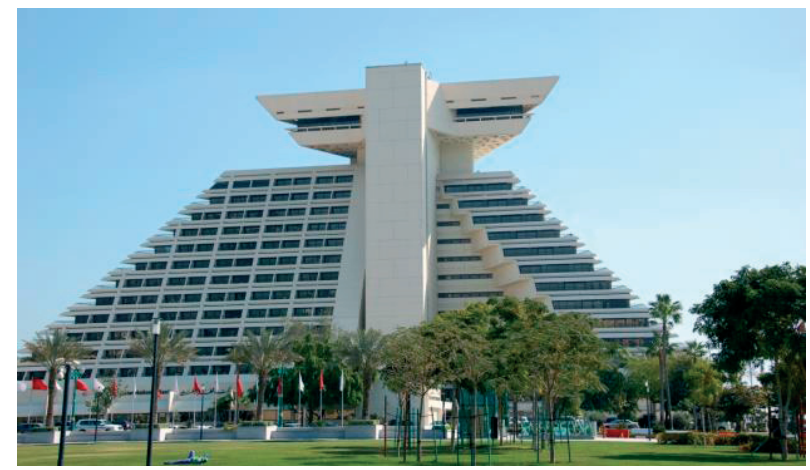

Rys. 5. Hotelu Sheraton (1979, projekt William Perreira), fot. wykonana przez autorów

\section{Doha Tower (Burj Qatar)}

Doha Tower, wzniesiony przy ulicy Al Corniche, jest jednym z najbardziej charakterystycznych obiektów stanowiących punkt orientacyjny Dohy, nadający współczesną formę sylwetce miasta (Rys. 6). Zaprojektowany przez francuskiego architekta Jeana Nouvela budynek nawiązuje stylem do poprzednich jego projektów, istniejącej 38-kondygnacyjnej Agbar Tower w Barcelonie i nie wybudowanej wieży Sans Fins w Paryżu. W 2012 roku uzyskał nagrodę jako najlepszy budynek świata nadaną przez organizację Council for Tall Buildings and Urban Habitat za szczególnie oryginalne rozwiązanie konstrukcyjne w formie żelbetowych pochylonych słupów typu diagrid ${ }^{6}[6,7]$.

Doha Tower ma 46 kondygnacji nadziemnych i 3 kondygnacje podziemne parkingu. Teren wokół wieży obniża się o 4,1 m od strony południowej i około $7 \mathrm{~m}$ od strony północnej. U podstawy wieża otoczona jest pierścieniem stalowego zadaszenia o szerokości $25 \mathrm{~m}$. W budynku zaprojektowano 4 wejścia znajdujące się na dwóch osiach symetrii, z których wejście zachodnie prowadzi do przestronnego lobby z antresolą. Przyziemie wieży poszerzone jest o dodatkowy obszar w formie pierścienia, w którym znajdują się restauracje, kawiarnie i mniejsze biura. Fasadę parteru tworzy przeszklona ściana o stalowych ramach z modułami równej szerokości. W centralnym trzonie konstrukcyjnym umieszczono dwie klatki schodowe i windy (Rys. 7). Od strony wschodniej zaprojektowano atrium z dodatkowymi szklanymi windami wznoszącymi się do 27 piętra co stanowi 112 metrów wysokości. Powierzchnie biurowe zajmują piętra od 1 do 44, natomiast na piętrach 45 i 46 zaprojektowano apartamenty. Generalnie rzut pięter jest powtarzalny oprócz wejściowego lobby z antresolą i dwóch ostatnich pięter. Dlatego pod względem formy geometrycznej możemy ten budynek zaliczyć do grupy „extruders”7. Budynek przekryty jest stalową kopułą o konstrukcji kratownicowej, której zwieńczenie stanowi iglica z piorunochronem. Nośna

Natomiast zewnętrzny wygląd budynków wysokich jest zdeterminowany przez materiały tworzące fasadę, a w szczególności przez rodzaj szkła. Szkło tworzące fasadę nie może przekraczać 60\% jej powierzchni oraz powinno tworzyć podwójną warstwę o grubości około $12 \mathrm{~mm}$.

${ }^{6}$ diagrid - ustrój nośny zamknięty na obwodzie, utworzony z powłok w postaci diagonalnej siatki, który pod obciążeniem poziomym zachowuje się jak rura. Powstałe przy zastosowaniu tego systemu obiekty mogą przybrać nieregularną formę lub strukturę o płynnej linii.

7 extruders - budynki tego typu mają na całej wysokości taki sam przekrój poprzeczny, przykładem może być bryła cylindryczna. W ramach tej grupy mogą występować następujące modyfikacje: a) poszczególne kondygnacje są ułożone jedna na drugiej w stałym nachyleniu, rzuty kondygnacji mogą mieć prosty lub zakrzywiony kontur; b) kondygnacje ułożone jedna na drugiej przy różnym kącie nachylenia, często w postaci prostych segmentów pochylających się w różnych kierunkach, płynnie połączonych z wygiętymi segmentami, mogącymi ulec przewężeniu wraz ze wzrostem wysokości. 
konstrukcja w postaci słupów pozwala na uzyskanie otwartej przestrzeni umożliwiającej swobodne zaplanowanie powierzchni biurowej do wysokości $3 \mathrm{~m}$.

Forma architektoniczna Doha Tower opiera się na typologii okrągłej wieży pokrytej fasadą z aluminium, nawiązującą do formy islamskiej zasłony mashrabiya z geometrycznym wzorem ośmioboków foremnych, powstałych w wyniku połączenia elementów w formie motyli w czterech różnych rozmiarach (Rys. 8). Elewacja składa się z pionowych płaszczyzn o różnej wielkości wzorów nałożonych na siebie i tworzących w elewacji różne strefy, z których dwie zaokrąglone są u góry. Liczba tych płaszczyzn zależy od orientacji wieży, w szczególności ma chronić przed promieniowaniem słonecznym, poprzez zacienienie. Gęstość strefy wynosi $25 \%$ na elewacji północnej, $40 \%$ na południowej i $60 \%$ na wschodniej i zachodniej. Aluminiowa konstrukcja osłaniająca jest częścią podwójnej fasady połączonej ze szklaną ścianą osłonową. Pomiędzy perforowaną elewacją, a szklaną ścianą znajdują się pomosty o szerokości około 1,5 $\mathrm{m}$. Szklana ściana osłonowa odgrywa ważną rolę w przepuszczaniu światła i zacienianiu wnętrza przestrzeni biurowej. Zaprojektowano ją jako konstrukcję segmentową o podziale naprzemiennym, wąskim i szerokim, zajmującym wysokość pełnej kondygnacji. Szkło wewnętrznej warstwy ścian osłonowych jest lekko odbijające i uzupełnia redukcję promieniowania słonecznego. Konstrukcja budynku i fasadowe pokrycie jest eksponowane, co czyni je ważnym elementem architektonicznym $[8,9,10]$.

Doha Tower jest budynkiem żelbetowym co jest typowe dla wielu komercyjnych wieżowców regionu West Bay. Budynek zaprojektowany jest na planie koła o średnicę $45 \mathrm{~m}$ i przekroju cylindrycznym. Podstawowe obciążenie pionowe budynku jest przenoszone przez system diagonalnej siatki (diagrid) pochylonych okrągłych słupów o średnicy $1,7 \mathrm{~m}$ w kształcie litery $\mathrm{X}$ tworzących konstrukcyjne powłoki umiejscowione na obwodzie okrągłego planu pięter. System ten przejmuje $75 \%$ poziomego obciążenia wiatrem. Przeplatane diagonalne żelbetowe słupy z ośmio-kondygnacyjnym modułem, zwężające się lekko ku górze, przejmują podstawowe obciążenia wraz $\mathrm{z}$ centralnym trzonem i sprężonym pierścieniem występującym na każdym piętrze. Budynek posadowiony jest na fundamencie zespolonym z płytą współpracującą z palami żelbetowymi.

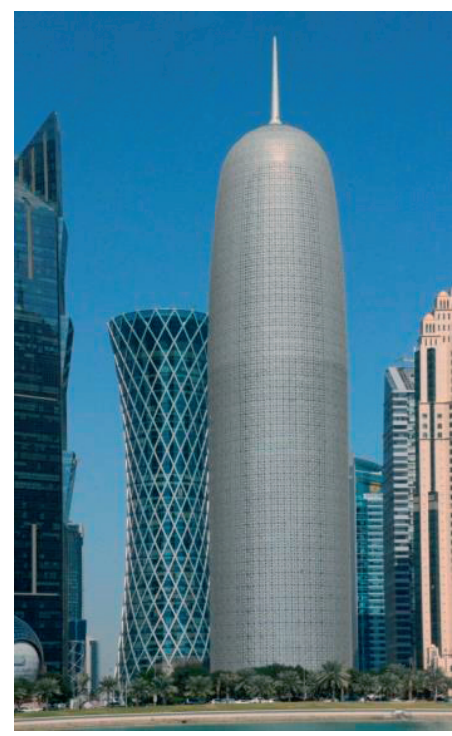

Rys. 6. Doha Tower (238, projekt Jean Nouvel), fot. wykonana przez autorów 


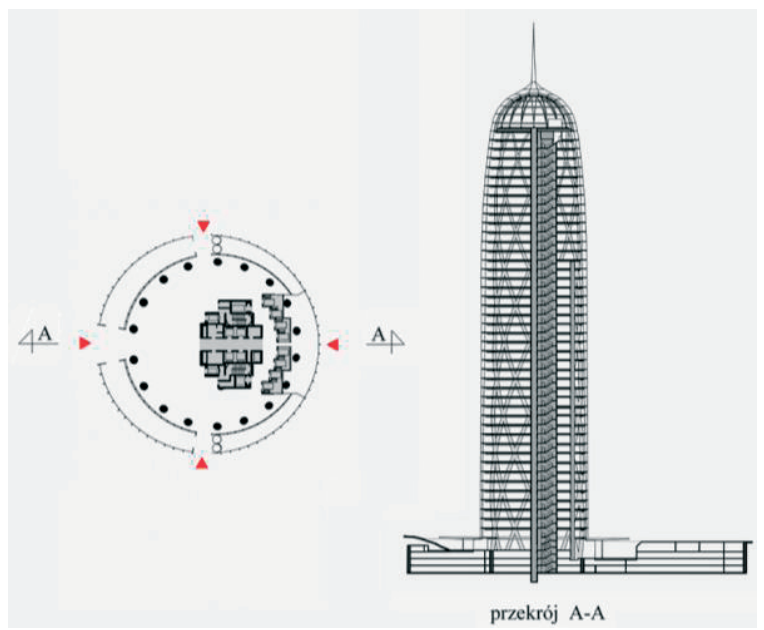

Rys. 7. Rzut parteru, przekrój, opracowanie autorów na podstawie [7,11]

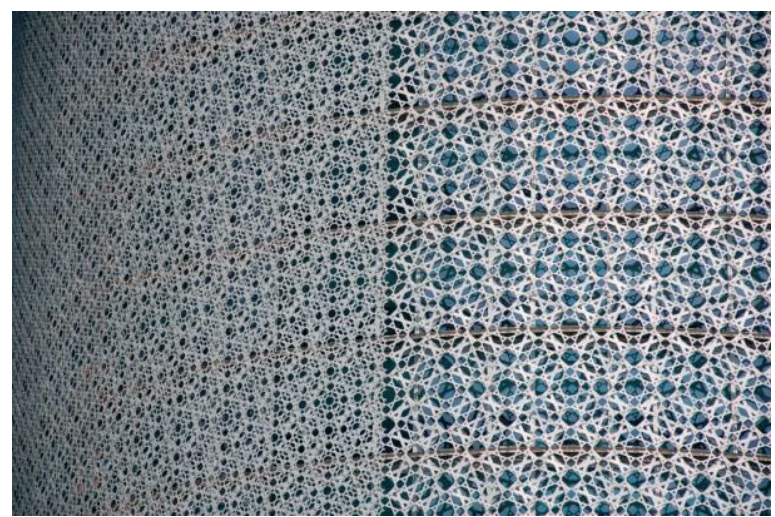

Rys. 8. Doha Tower - Fasada $\mathrm{z}$ aluminium $\mathrm{w}$ formie islamskiej zasłony mashrabiya $\mathrm{z}$ geometrycznym wzorem w kształcie motyla, fot. wykonana przez autorów

\section{Al Bidda Tower (Platinum Tower)}

Budynek Al Bidda Tower jest zlokalizowany na rozwijającym się architektonicznie obszarze wokół głównej ulicy Al Corniche (Rys. 9). Ten oryginalny budynek został zaprojektowany przez pracownię architektoniczną GHD Global [11]. W 2011 roku ze względu na oryginalną konstrukcję budynek uzyskał tytuł wieży roku nadany przez CW Qatar Awards. Al Bidda Tower jest siedzibą wielu prestiżowych organizacji. Między innymi jest kwaterą główną instytucji Katara, która jest odpowiedzialna za promocję katarskiej tożsamości poprzez działalność kulturalną i sportową. Obecnie instytucja ta jest skupiona na przygotowaniach do organizacji mistrzostw świata w piłce nożnej FIFA 2022.

Al Bidda Tower ma 44 kondygnacje nadziemne i 1 kondygnację podziemną z przeznaczeniem na parking. Dodatkowo do budynku przylega oddzielny ośmiokondygnacyjny parking. Wejście do budynku znajduje się na poziomie terenu od strony zachodniej i prowadzi do westybulu, który otacza wieżowiec od strony północnej i zachodniej. Westybul wsparty jest na stalowych słupach zwieńczonych segmentowym naczółkiem. Jego dach otrzymał formę wklęsło-wypukłą zakończoną aluminiowym, ażurowym daszkiem. Fasadę wykonano jako szklaną ścianę osłonową zamocowaną punktowo do wewnętrznych słupów. 


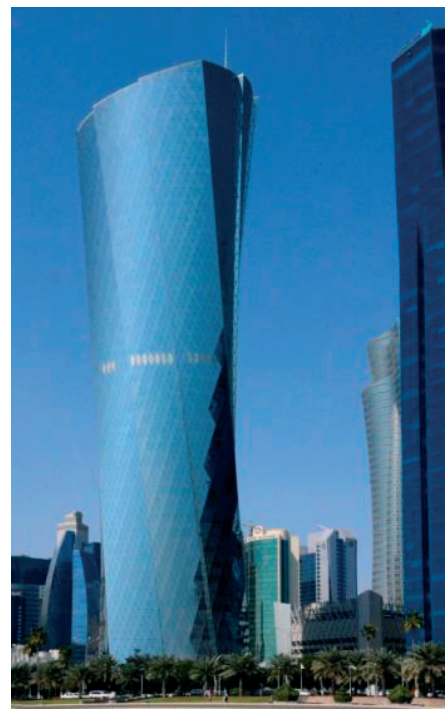

Rys. 9. Al Bidda Tower (187 m, 2009, projekt GHD Global), fot. wykonana przez autorów

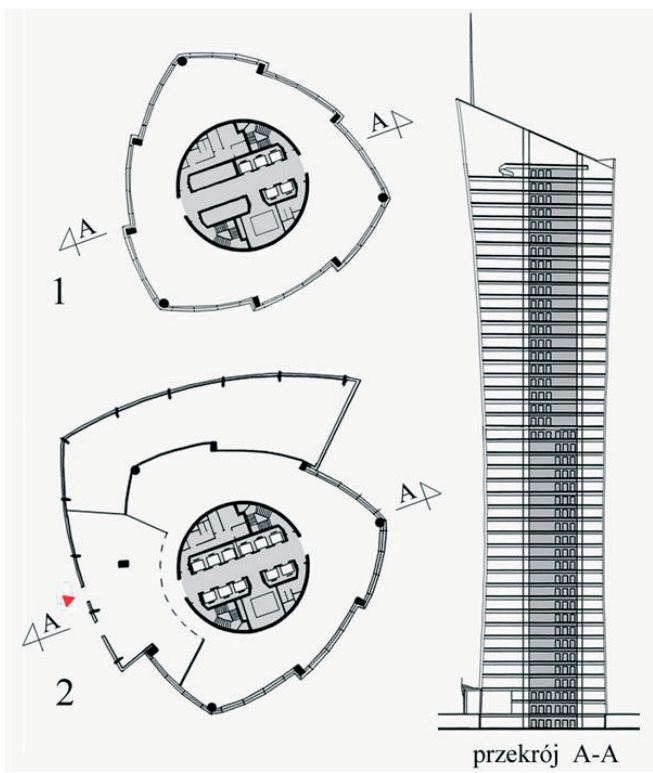

Rys. 10. Al Bidda Tower - Rzuty: 1) parteru, 2) 14 kondygnacji; przekrój, opracowanie autorów na podstawie [11]

Powierzchnie biurowe zajmują piętra od 1 do 39 . Na 40 piętrze znajduje się klub z panoramicznym widokiem na zatokę, a na kolejnych piętrach centrum zdrowia, restauracja i klub fitness. Budynek zaprojektowany jest na planie wypukłego trójkąta z dwoma ryzalitami w każdym boku (Rys. 10). Również zróżnicowana jest jego szerokość, najmniejsza jest na 14 kondygnacji, a następnie wraz z wysokością zwiększa się sukcesywnie, aż do uzyskania maksimum na szczycie, przyjmując wartość większą niż u podstawy. W centralnym trzonie konstrukcyjnym umieszczono dwie klatki schodowe i windy. 
Płyty stropowe na każdej kondygnacji mają różną powierzchnię, najmniejsza jest na 40 kondygnacji. Konsekwentnie każda płyta stropowa jest inna zarówno pod względem geometrii jak i jej lokalizacji. Pod względem formy geometrycznej można go zaliczyć do

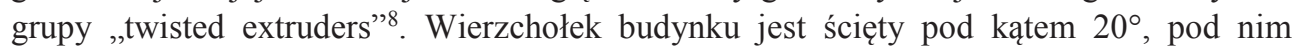
znajduje się 5 kondygnacyjne atrium w formie stalowej ramy. Zewnętrzna fasada budynku wykonana jako strukturalna, składa się ze ściany osłonowej w formie trójkątów tworzących diagonalną siatkę oraz okładziny z oddzieloną szybą $[8,9,10]$. W ciągu dnia wielowarstwowe szkło refleksyjne odbija w różnych kierunkach światło słoneczne, a w nocy wewnętrzne światło. Rezultatem tego jest błyszcząca fasada podobna do lustra (Rys. 11).

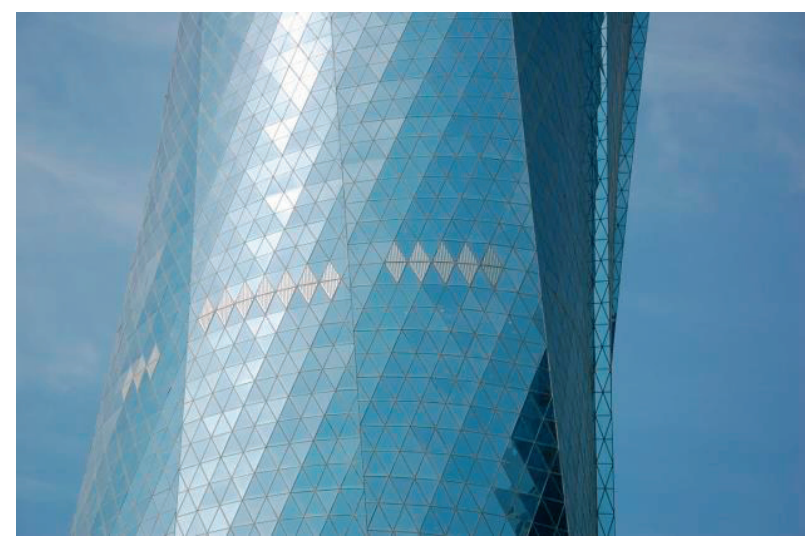

Rys. 11. Al Bidda Tower - Fasada budynku w formie trójkątów odbijających kształt diagonalnej siatki, fot. wykonana przez autorów

Budynek Al Bidda Tower jest budynkiem stalowo-żelbetowym skręconym o $60^{\circ}$ na całej swojej wysokości. Konstrukcja Al Bidda Tower składa się z okrągłego żelbetowego trzonu i sprężonych kablobetonowych płyt stropowych zamontowanych do poziomu 30 piętra. Płyty stropowe sprężone kablobetonem w trzech narożnikach są podparte promieniście pasem belek rozpiętych pomiędzy zewnętrznymi słupami i trzonem oraz obwodowymi belkami rozpiętymi pomiędzy słupami. Trzon budynku ma stałą grubość $50 \mathrm{~cm}$ do poziomu 24 piętra, powyżej którego ulega pocienieniu do $40 \mathrm{~cm}$. Na zewnątrz na obwodzie usytuowanych jest 9 zewnętrznych żelbetowych słupów o zróżnicowanym przekroju, które pochylają się wraz ze skrętem budynku i diagonalna siatka stalowych stężeń. Słupy o przekroju kołowym mają średnicę 1,4 m, natomiast o przekroju prostokątnym wymiary $1 \mathrm{~m}$ x 1,7 m. Powyżej 30 piętra belki stropowe mają konstrukcję zespoloną, kompozytową natomiast zewnętrzne słupy konstrukcję stalową. Na całej wysokości budynku, na obwodzie, występuje stalowe stężenie w formie diagonalnej siatki, którą odbija ściana osłonowa. Z powodu skręcenia budynku, diagonalne stężenie po przeciwnej stronie skręcenia jest bardziej obciążone niż stężenie opadające ze skręceniem. Wszystkie stężenia składają się ze stalowych przekrojów rurowych. Grubość ścian i przekroje stężeń zmieniają się wraz z wysokością. Stężenia są połączone z obwodowymi żelbetowymi belkami i kolumnami za pomocą przegubowych łączników. Boczne obciążenia są przejmowane przez trzon i zewnętrzny stalowy diagonalny system stężeń. Obciążenie skręcające wynikające z pochylonych

8 twisted extruders - budynki tego typu mają formę skręconej bryły, w której kondygnacje ułożone jedna na drugiej mają stałe nachylenie, a ich rzuty mają zakrzywiony kontur. 
słupów, jak również obciążenie poziome są przenoszone przez wewnętrzne stężenia i trzon z płytami stropowymi działającymi jak diafragma. Budynek posadowiony jest na fundamencie zespolonym z płytą współpracującą z palami żelbetowymi.

\section{Tornado Tower (Qipco Tower)}

Tornado Tower poszerza panoramę wieżowców z jej unikalną architekturą (Rys. 12). Ten jedyny w swoim rodzaju budynek został zaprojektowany przez firmę architektoniczną Cico Consulting Architects and Engineers [13]. Ze względu na swoją formę architektoniczną i konstrukcję w 2009 roku dostał nagrodę za najlepszy budynku Bliskiego Wschodu i Afryki, nadaną przez organizację Council for Tall Buildings and Urban Habitat. Nazwa Tornado miała odzwierciedlać jego hiperboloidalną formę przypominającą „wirujące" tornado na pustyni. Pod względem formy geometrycznej można go zaliczyć do grupy „squeezed rotors"

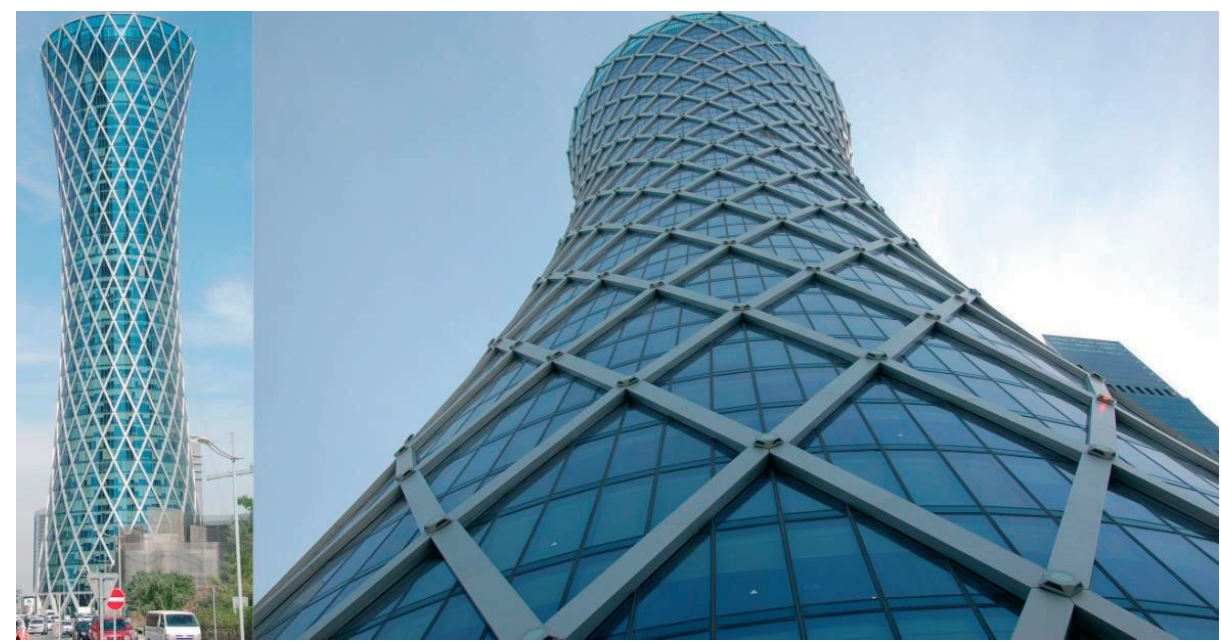

Rys. 12. Tornado Tower (195 m, projekt Cico Consulting Architects and Engineers), fot. wykonana przez autorów

Tornado Tower ma 51 kondygnacji nadziemnych i 3 kondygnacje podziemne z przeznaczeniem na parking. Wejście do budynku znajduje się na poziomie terenu od strony południowej prowadząc do lobby $\mathrm{z}$ antresolą. W centralnym trzonie konstrukcyjnym utworzono hall na planie wklęsłego trójkąta do którego przylegają zespoły wind i klatki schodowe (Rys. 13). W przyziemiu zaprojektowano podcień o wysokości dwóch kondygnacji. Zajmuje on przestrzeń pomiędzy słupami o przekroju prostokątnym, a szklaną fasadą budowli. Parter od wyższych kondygnacji wyraźnie oddziela gzyms utworzony ze skośnie ściętej płyty, przecięty diagonalną konstrukcją słupów w każdym przęśle. Na pierwszej kondygnacji, która ma średnicę $60 \mathrm{~m}$, znajduje się hall, restauracja i bank. $\mathrm{Na}$ drugiej kondygnacji zlokalizowano cafeterię i salę konferencyjną, a na 27 centrum rekreacyjne $\mathrm{z}$ fitnessem i barem. Pozostałe piętra zajęte są przez biura. Trzy najwyższe piętra Tornado Tower są otoczone przez tarasy widokowe z możliwością oglądania panoramy o zasięgu $360^{\circ}$, natomiast na dachu wieży zlokalizowano lądowisko dla helikopterów.

${ }^{9}$ squeezed rotors - budynki tego typu mają formę wklęsłej bryły obrotowej, której oś obrotu może mieć bardzo złożoną krzywiznę. 


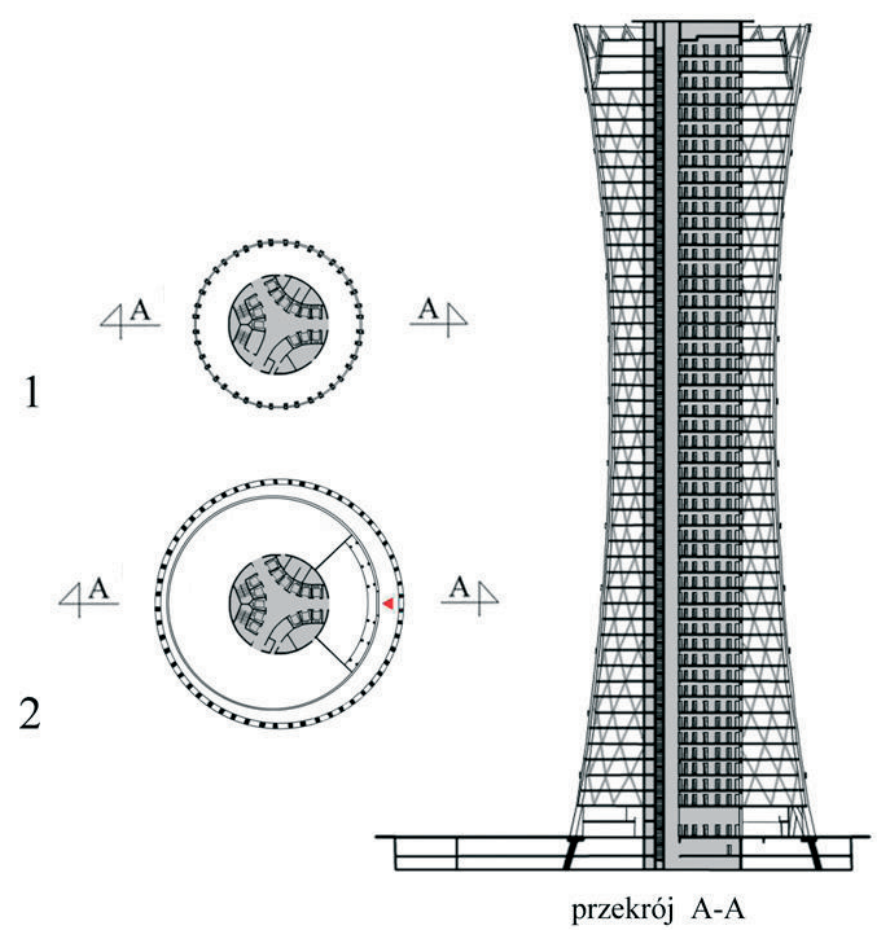

Rys. 13. Tornado Tower - Rzuty: 1) parteru, 2) 25 kondygnacji; przekrój, opracowanie autorów na podstawie [14]

Fasada budynku to układ stalowej diagonalnej siatki odpowiadającej wewnętrznej konstrukcji i szklanej ściany osłonowej. W co drugiej kondygnacji w diagonalnej siatce typu X w środkowym węźle zaakcentowano formę główki śruby. Zewnętrzną diagonalną siatkę wykonano jako stalową kratownicę nośną pokrytą aluminiową nakładką (Rys. 14). Zastosowana fasada segmentowa składa się z ponad 6000 paneli typu Wicona ${ }^{10}$ wykonanych w 50 różnych wymiarach (Rys. 15), które były łączone i przeszklone poza miejscem budowy. Różne wymiary paneli na każdym piętrze pozwoliły na uzyskanie krzywizny budynku bez potrzeby stosowania zakrzywionego szkła. Zastosowano dwa rodzaje szkła o grubości $34 \mathrm{~mm}$, odbijające promienie słoneczne w obszarze okiennym i matowe pomiędzy stropami. Panele okienne o wysokości jednej kondygnacji mają jednakową szerokość i łączą się z wąskim pasem poziomej szyby o szerokości stropu. Segmentowe panele są połączone z zewnętrzną diagonalną konstrukcją, która jest kluczowym elementem architektonicznym budynku. Na konstrukcji tej zainstalowano oświetlenie w punktach węzłowych, dające w nocy spektakularny efekt wizualny. Dynamiczne oświetlenie wieży zaprojektowane przez niemieckiego artystę Thomasa Erndte, sprawia wrażenie wirującego tornado na pustyni. System oświetlenia zaprogramowany przez firmę Siemens, umożliwia prezentację ponad 35000 różnych wzorców oświetlenia. Tornado Tower położony na działce o powierzchni $18500 \mathrm{~m}^{2}$ zajmuje jedynie $3000 \mathrm{~m}^{2}$, taka lokalizacja ma na celu pozostawienie wolnej przestrzeni przedpola dla lepszej ekspozycji unikalnej geometrycznej formy wieżowca.

\footnotetext{
${ }^{10}$ Panele Wicona - systemy profili aluminiowych stosowane w ścianach osłonowych, produkowane przez niemiecką firmę Wieland Werke z siedzibą w Ulm.
} 


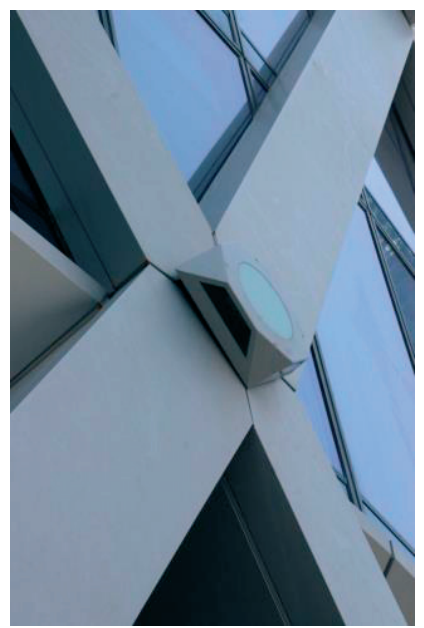

Rys. 14. Tornado Tower - element diagonalnej siatki w formie stalowej kratownicy pokrytej aluminiową nakładką ze śrubą, fot. wykonana przez autorów

Konstrukcja budynku składa się z centralnego żelbetowego trzonu o średnicy 23,8 m i obwodowej diagonalnej siatki stalowych słupów pełniących funkcję powłoki. Powłoka zwiększa sztywność obwodowych ścian na działanie sił poziomych. Żelbetowy trzon budynku jest połączony z obwodową, powłokową konstrukcją promienistymi stalowymi belkami, które są zwieńczone kompozytową płytą stropową Belki poddane są znacznym siłom rozciągającym wynikającym z kształtu budynku. Płyty stropowe zaprojektowano jako membrany spinające stalową diagonalną konstrukcję z żelbetowym trzonem. Budynek posadowiony jest na fundamencie zespolonym z płytą żelbetową o grubości 2,7 m wzmocnioną palami żelbetowymi o długości 14 i $9 \mathrm{~m}$.

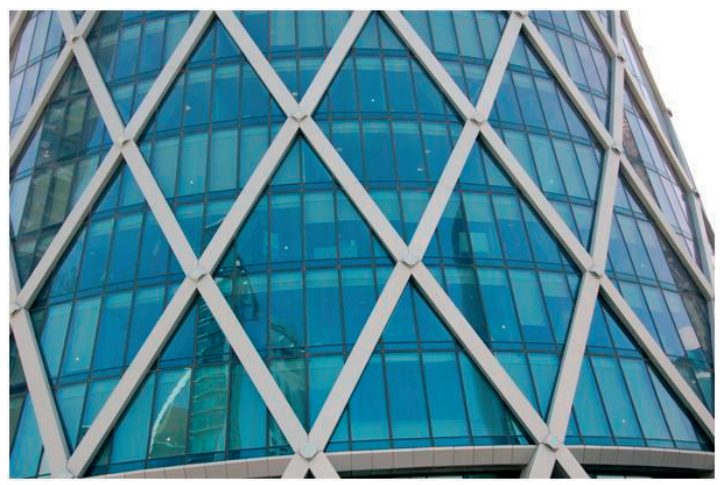

Rys. 15. Tornado Tower - fasada segmentowa składająca się z paneli Wicona o różnych wymiarach, fot. wykonana przez autorów

\section{Aspire Tower (Torch Tower)}

Aspire Tower jest wielofunkcyjnym wieżowcem zlokalizowanym w kompleksie sportowym Aspire Zone w skład którego wchodzą: stadion Khalifa, centrum sportowe Aspire Dome, pływalnie Hamad Aquatic Center i korty tenisowe National Teams Club (Rys. 16). Aspire Tower została zaprojektowana przez architekta Hadi'ego Simaana wraz z zespołem projektowym Arup [15]. Budynek ten był najważniejszą budowlą w trakcie XV igrzysk 
azjatyckich w 2006 roku. Swoim kształtem przypomina ogromną pochodnię, w której na czas igrzysk utrzymywano symboliczny elektryczny płomień. Pod względem formy geometrycznej można go zaliczyć do grupy „squeezed rotors”. W 2008 roku wieża uzyskała nagrodę w konkursie Middle East Lighting Design Awards za najlepszy projekt zewnętrznego oświetlenia budynku zlokalizowanym na Bliskim Wschodzie.

Aspire Tower jest budynkiem stalowo-żelbetowym, który ma 36 kondygnacji. W wieżowcu wydzielono 5 modułów o różnej wysokości i funkcjach użytkowych. W pierwszym module znajduje się recepcja z dużą powierzchnią obejmującą dwie kondygnacje, ośmiokondygnacyjny 5 gwiazdkowy hotel, muzeum sportu, centrum biznesowe i restauracja ze wspornikowym basenem na wysokości $80 \mathrm{~m}$. Powyżej, w następnych czterech modułach, znajdują się centrum zdrowia, apartamenty prezydenckie, platforma widokowa na wysokości 240 m oraz obrotowa restauracja (Rys. 17, 18). Na samym szczycie żelbetowego trzonu zaprojektowano 62 metrowej wysokości stalową kratową powłokę osłaniającą konstrukcję $\mathrm{w}$ formie odwróconego stożka podpierającego płonący znicz (Rys. 19).

Na osi północno-południowej znajdują się wejścia, z których południowe prowadzi do recepcji hotelu, natomiast północne na piętro. Dodatkowe wejście północno-wschodnie jest skierowane w kierunku Aspire Dome. W przyziemiu po stronie wschodniej w obszernym lobby i jego antresoli umieszczono kawiarnie. Centralny trzon i otaczająca go część użytkowa została zaprojektowana na planie koła o średnicy około $37 \mathrm{~m}$. Kompleks wind w części północno-wschodniej przylega do trzonu, w którym umieszczono dwie klatki schodowe. Panoramiczne windy tworzą pion rozdzielający część hotelową. W elewacji hotelu widoczna jest konstrukcja stalowych ram oraz segmentowe okna o podziałach pionowych. Ramy te łączą się $\mathrm{z}$ dwupowłokową fasadą zewnętrzną poprzez system kratownic (Rys. 20). Zewnętrzna elewacja składa się z segmentów o podziale pionowym wzmocnionych stalowymi słupkami. Słupki te połączone są z zewnętrzną ramą stanowiącą konstrukcję wsporczą dla powłoki, która ma formę stalowej siatki.

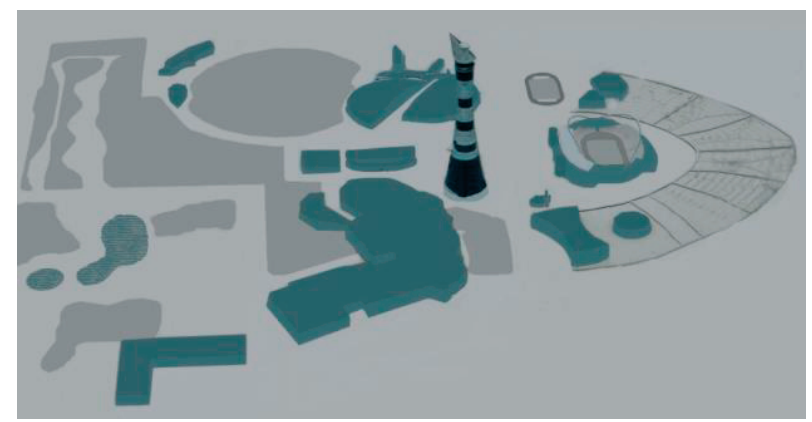

Rys. 16. Zespół obiektów w kompleksie sportowym Aspire Zone, opracowanie autorów na podstawie zdjęcia wykonanego in situ

Centralną częścią budowli jest żelbetowy trzon, którego średnica u podstawy wynosi $14 \mathrm{~m}$ i zmniejsza się do $11 \mathrm{~m}$ na poziomie restauracji. Osiąga on wysokość $238 \mathrm{~m}$ i jest zwieńczony odwróconym stożkiem. W celu zniwelowania oddziaływań dynamicznych, na szczycie wieży umieszczono tłumik drgań w formie wahadła.

Trzon stanowi podparcie dla modułowo usytuowanych pięter i zewnętrznej stalowej konstrukcji. Wszystkie moduły pięter są podparte wspornikami o długości dochodzącej do 11,3 m. Najdłuższy wspornik o długości 12 m występuje na kondygnacji 19, gdzie znajduje się basen (Rys. 21). Stropy wychodzące od centralnego trzonu zawierają stalowe belki, 
które podpierają płyty żelbetowe. Ogólny układ stropów jest taki, że podstawowe belki są zamontowane promieniście pomiędzy stalowymi słupkami i żelbetowym trzonem z obwodowymi belkami drugorzędnymi. Stropy w apartamentach prezydenckich, muzeum i restauracji są dodatkowo podparte przez ukośne stalowe wsporniki u podstawy każdego modułu. Dolny strop platformy widokowej ma podobny kład konstrukcyjny, podczas gdy górny strop jest żelbetowym wspornikiem wychodzącym bezpośrednio od szczytu trzonu. Dla kontrastu stropy hotelu są podparte przez system pionowych kratownic zlokalizowanych w części ścian występujących pomiędzy pokojami, które u podstawy wspierają się na żelbetowym wspornikowym pierścieniu i trzonie poniżej czwartej kondygnacji.

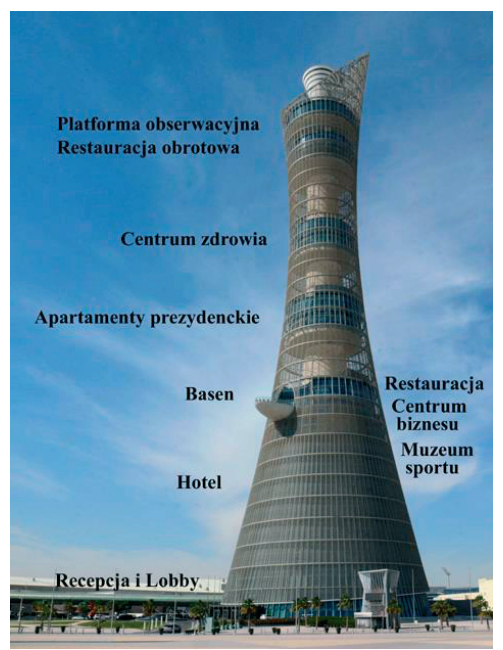

Rys. 17. Aspire Tower (300 m, 2007, projekt Hadi Simaan wraz z zespołem projektowym Arup), fot. wykonana przez autorów

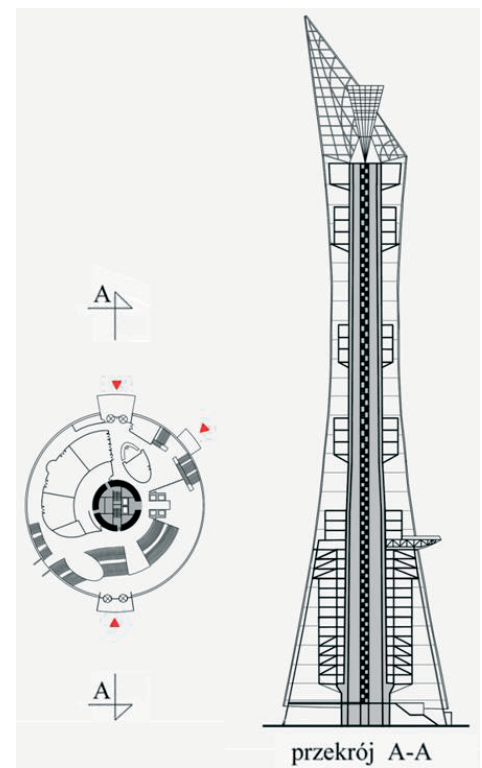

Rys. 18. Aspire Tower - Rzut parteru z antresolą, przekrój, opracowanie autorów na podstawie [11] 


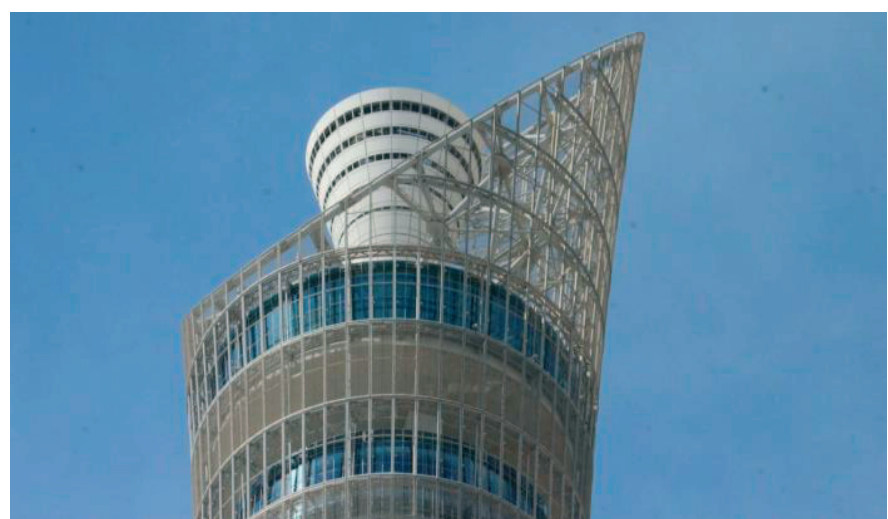

Rys. 19. Aspire Tower - konstrukcja 62 metrowej stalowej kratowej powłoki osłaniającej stożek, w którym znajduje się znicz olimpijski, fot. wykonana przez autorów

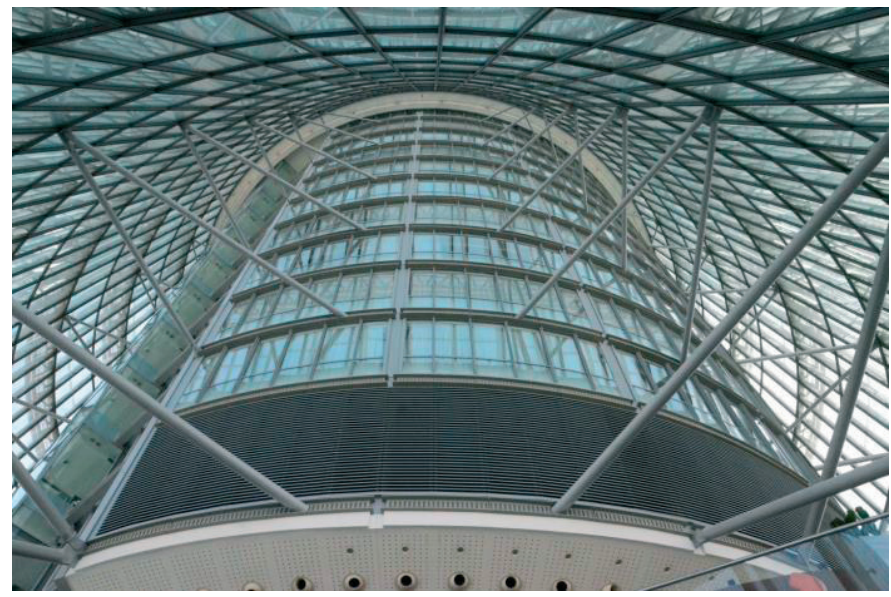

Rys. 20. Aspire Tower - wnętrze z częścią hotelową, fot. wykonana przez autorów
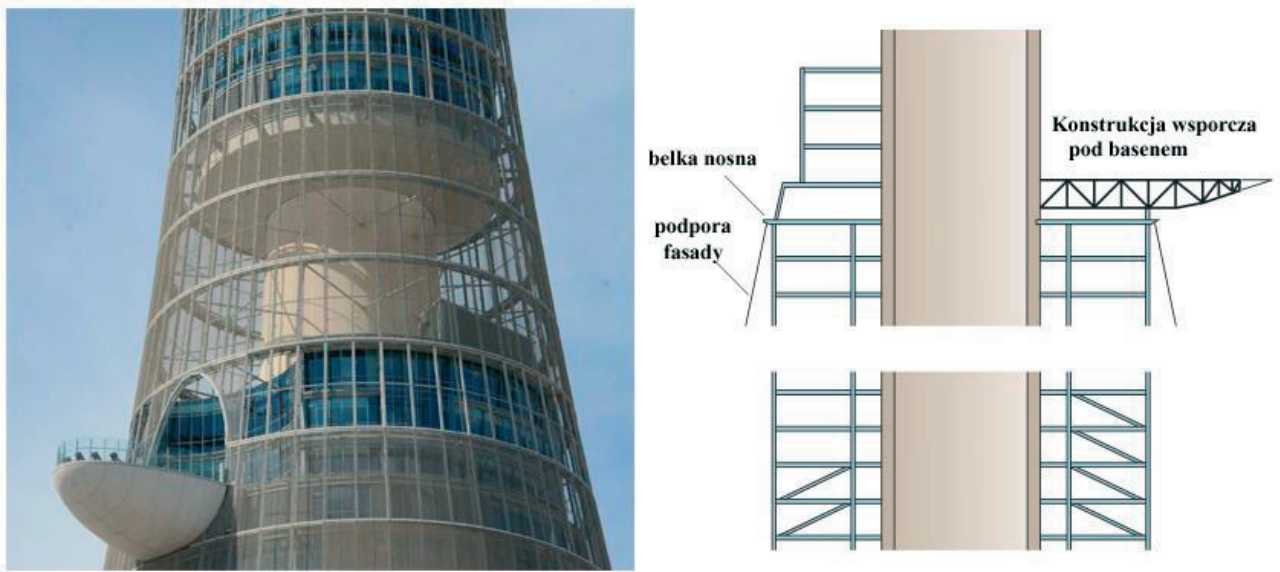

Rys. 21. Aspire Tower - konstrukcja wsporcza basenu, fot. i opracowanie konstrukcji wykonane przez autorów 


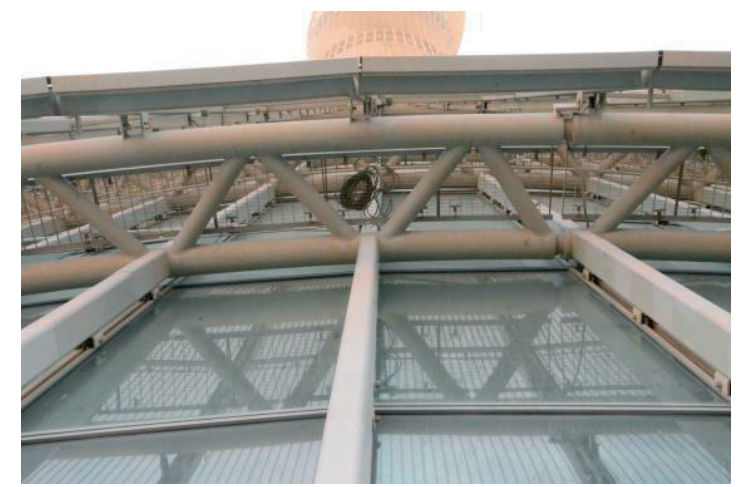

Rys. 22. Aspire Tower - konstrukcja stalowej fasady, fot. wykonana przez autorów

Wieża otoczona jest nierdzewną okładziną dającą strefowo jednolitą powierzchnię dla całego budynku. Ta stalowa konstrukcja jest usztywniona stalowymi pierścieniami w pasach co $8 \mathrm{~m}$. Ciężar obwodowych okładzin jest przenoszony przez tą samą konstrukcję nośną, która podpiera stropy (Rys. 22). Stalowa konstrukcja otaczająca trzon jest konstrukcją usztywniającą i wraz z zewnętrzną powłoką szklaną jest energooszczędna. Wieża jest posadowiona na żelbetowej płycie fundamentowej o średnicy $37,3 \mathrm{~m}$ i grubości $7 \mathrm{~m}$ oraz na 77 palach razem z nią współpracujących.

\section{Uwagi końcowe}

Środowisko budowlane arabskich miast Bliskiego Wschodu, a w szczególności Kataru przeszło ogromną transformację, co w rezultacie dało znaczące fundamentalne zmiany w architekturze tego rejonu świata. W architekturze Dohy zaczęto odchodzić od tradycyjnych arabskich motywów, pod koniec lat 30-tych i ten trend był kontynuowany wraz z bogaceniem się kraju w następnych dekadach. Miasta i regiony tego rejonu stanęly przed wyzwaniem dynamicznego rozwoju jako konsekwencja globalizacji. Ogromny rozwój ekonomiczny Kataru spowodował wzrost przepływu ludności odmiennych kulturowo. Różnorodność kultur, otwarty rynek i globalizacja odegrały ważną rolę w nowym stylu architektury tego kraju. W tym samym czasie napływ zagranicznych projektantów i architektów przyniósł nowe i innowacyjne pomysły, które odbiegały coraz bardziej od tradycyjnego stylu. Przykładowo, europejski styl balkonów zaczął pojawiać się w tradycyjnych katarskich domach z dziedzińcami, dodawano także więcej pięter do średnio-wysokich budynków. W rezultacie Katar wyłonił się jako globalne centrum dla mediów, edukacji, kultury i finansów dzięki ogromnym inwestycjom i kilkunastu zrealizowanym projektom, takim jak: kanał telewizyjny Al Jazeera, strefa ekonomiczna Doha oraz Centrum Edukacyjne, Naukowe i Środowiskowe. Rozwój różnych systemów konstrukcyjnych spowodował wznoszenie budynków o bardzo skomplikowanej formie i różnym przeznaczeniu. W Katarze architektura współczesna może być zdefiniowana jako mieszanka architektury europejskiej, azjatyckiej, islamskiej, arabskiej oraz lokalnych trendów. Od około 150 lat trwa nieustanny wyścig o wybudowanie najwyższego budynku świata, do którego dołączają coraz to inne miasta. W wyniku dynamicznego rozwoju również w Dausze zaczęto budować budynki wysokościowe, gdyż wieżowce to symbol nowoczesności, dobrej kondycji finansowej i atrakcyjności dla inwestorów. Innym powodem wznoszenia budynków wysokościowych o stosunkowo dużym zagęszczeniu to wysokie ceny gruntów, nawet w porównaniu z Dubajem, czy Nowym Jorkiem. 
Od 2007 roku w Dausze wybudowano 33 budynki powyżej 150 m, a 7 jest w trakcie realizacji. Analizując materiał konstrukcyjny, z którego zostały wybudowane wieżowce, można wywnioskować coraz większe zainteresowanie betonem jako głównym materiałem konstrukcyjnym, i tak wśród wybudowanych budynków 32 są żelbetowe, 3 stalowożelbetowe i 5 kompozytowo zespolone. Ponadto fasady większości budynków wykonane są z wielowarstwowego szkła odbijającego promienie słoneczne, co jest szczególnie istotne dla tego klimatu. Oprócz tego elewacje współdziałają $\mathrm{z}$ systemami wentylacyjnoklimatycznymi, stanowiąc część układów oszczędzających energię z automatyką opartą na systemach komputerowych [16]. Najlepszym przykładem wieżowca w pełni to realizującym jest Tornado Tower $\mathrm{z}$ globalnie zarządzającym systemem komputerowym firmy Siemens. W przypadku funkcji użytkowych, 20 spośród zrealizowanych wieżowców spełnia funkcje biurowe, 8 hotelowe, 5 mieszkalne, 1 mieszane hotelowo-biurowe i 6 mieszane mieszkalno-biurowe. Podsumowując należy stwierdzić, że główny trend w budownictwie wysokościowym w Katarze, to wybudowanie wieżowca stabilnego, funkcjonalnego, energooszczędnego i ekologicznego.

Obecnie główną wizytówką tego kraju stały się ikoniczne wieżowce o unikalnej geometrii zlokalizowane w dzielnicy biznesowej West Bay oraz niezwykły kompleks sportowy Aspire Zone z wieżą Aspire Tower. Wśród wyróżniających się wieżowców należy wymienić Doha Tower, Al Bidda Tower oraz Tornado Tower, które obecnie stanowią znak rozpoznawczy Kataru na całym świecie.

Przedstawione obiekty wyróżniają się różnymi rozwiązaniami fasad, w większości dwupowłokowych. Fasady składają się ze szklanej ściany osłonowej i zewnętrznej powłoki, która przyjmuje formę stalowej siatki o wzorach geometrycznych (Doha Tower), prostokątnego podziału (Aspire Tower) i diagonalnej siatki (Tornado Tower). W Al Bidda Tower całą elewację stanowią trójkątne okna, natomiast w Tornado Tower zastosowano okna o podziałach prostokątnych. Poprzez zastosowanie różnych powłok w oknach, wieżowce otrzymały fasady w różnych odcieniach niebieskiego koloru np. na tle ciemno niebieskiego szkła w Tornado Tower wyróżnia się jasna, aluminiowa konstrukcja fasady. Oprócz niepowtarzalnej formy geometrycznej wszystkie budynki łączy podobny system konstrukcyjny w postaci centralnego żelbetowego trzonu w środku budynku i obwodowego sytemu stalowej lub żelbetowej konstrukcji powłokowej typu diagrid połączonej z trzonem za pomocą promienistych belek i płyt stropowych. Budynki są posadowione na fundamentach zespolonych składających się z płyty żelbetowej i współpracujących z nią pali żelbetowych. Zastosowane pale zmniejszają zginanie płyty i osiadanie budynku.

Projektanci tych oryginalnych budynków osiągnęli także inne cele, polegające na stworzeniu budynków inteligentnych, łączących wszystkie dyscypliny technologiczne, zapewniające energooszczędność i maksymalny poziom bezpieczeństwa, co można potwierdzić poprzez ich analizę.

\section{Literatura:}

1. Jodidio P., Halbe R (fotografie). The New Architecture of Qatar, Skira, Rizooli, 2015.

2. Jaidah I. The History of Qatari Architecture, Skira Rizooli, 2010.

3. Mahgoub Y. Towards Eco-Tall Buildings in Doha. CTBUCH Research Paper, Seoul Conference, 2011.

4. Wiedmann F., Salama A., Thierstein A. Urban Evolution of the City of Doha. An Investigation into the Impact of Economic Transformations on Urban Structures, METU JFA 2 (2012) 35-61.

5. Mahgoub Y., Abbara B. Tall Buildings Legislations in Doha, Qatar, Procedia, Social and Behavioral Sciences 36 (2012) 640-649. 
6. Karakuş G. Doha Tower, On Site Review Report, 2016.

7. Terranova A., Spirito G. New Urban Giants. The Ultimate Skyscrapers, White Star Publisher, 2008.

8. Boake T. M. Hot Climate Double Façades: Avoiding Solar Gain. Façade Tectonics Journal 14 (2014) 2-25.

9. Rajczyk M., Respondek Z. Systemy Elewacji z zastosowaniem szkła modyfikowanego. Świat Szkła 7 (2010) 251-260.

10. Ben-Nail Abu Sief S. Comparison of Different Facades for High-rise Buildings in Hot and Cold Climates in Terms of Material Usage. Praca dyplomowa, Eastern Mediterranean University, Gazimaĝusa, Cypr, 2014.

11. Van Uffelen C. Skyscrapers, Braun, 2012.

12. Round I. Al Bidda (Platinum) Tower, Doha. Proceedings of ASEC 2014 Conference, Auckland, Nowa Zelandia, 2014, s.1-5.

13. FlowCon International. Tornado Tower, Doha, Qatar, czerwiec 2016, s.1-5.

14. Korsavi S., Maqhareh M. R. The Evolutionary Process of Diagrid Structure Towards Architectural, Structural and Sustainability Concepts: Reviewing Case Studies. Journal of Architectural Engineering Technology 3(2) (2014) 1-11.

15. Chikaher G., Hirst J. Aspire Tower, Doha, Qatar. The Arup Journal 2 (2007) 11-13.

16. Pawłowski A., Cała I. Budynki wysokie. Oficyna wydawnicza Politechniki Warszawskiej, 2013.

\title{
Contemporary architecture of high-rise buildings in Doha - the capital of Qatar
}

\author{
Jerzy Szołomicki ${ }^{1}$, Hanna Golasz-Szołomicka ${ }^{2}$ \\ ${ }^{l}$ Wrocław University of Technology,e-mail: jerzy.szolomicki@pwr.edu.pl \\ ${ }^{2}$ Wrocław University of Technology, e-mail: hanna.golasz-szolomicka@pwr.edu.pl
}

\begin{abstract}
The article presents elements of architectural and construction analysis of selected high-rise buildings from Qatar Doha, located in the West Bay business district and the Aspire Zone sports complex. Analyzing the Doha architecture, it can be said that it is now a rapidly growing metropolis, which can be considered as the most advanced architectural city in the world, even compared to Dubai. The construction boom caused the building of skyscrapers, sports facilities, and iconic museums. The first part of the article draws attention to how Doha has joined the world's most exciting cities over the last several years due to the rapid economic development resulting from the discovery of huge oil and gas fields. The turning point was the organization of the XV Asian Games in 2006. As a result of the economic success of these games over 100 tall buildings were planned to be built in the West Bay business district and adjacent districts. The architectural development of the city could not have taken place without the participation of prominent foreign architects such as Jean Nouvell and Ieoh Pei. Contemporary Qatar architecture can be defined as a mix of European, Asian, Islamic, Arabic architecture and local trends. However, the most recognizable buildings in this country are iconic skyscrapers with unique geometry which are characterized in the second part of that article. Among the skyscrapers should be mentioned first of all: Doha Tower, Al Bidda Tower, Tornado Tower and Aspire Tower located in the Aspire sports complex. These buildings are currently the world-famous Qatar highrise buildings.
\end{abstract}

Keywords: Qatar architecture, high-rise buildings, Diagrid construction system. 